ISSN 0103-5150

Fisioter. Mov., Curitiba, v. 30, n. 1, p. 107-14, Jan./Mar. 2017

Licenciado sob uma Licença Creative Commons

DOI: http://dx.doi.org/10.1590/1980-5918.030.001.A011

\title{
Symptomatic profile of infected individuals with HIV/AIDS in a physiotherapy department
}

\author{
Perfil Sintomatológico de indivíduos com \\ HIV/AIDS em um setor de fisioterapia
}

Tamaiara Barbosa do Amorim, Elis Passos Santana, Kionna Oliveira Bernardes Santos*

Universidade Federal da Bahia (UFBA), Salvador, BA, Brazil

\begin{abstract}
Introduction: Changes in the profile of infected individuals with HIV and the chronicity of this condition become necessary a better understanding about the clinical changes caused by the disease. Objective: This study characterizes the physical symptoms of infected individuals with HIV in a physiotherapy department of a specialized HIV treatment center. Methods: A descriptive study with quantitative analysis was performed. All registered users in the physiotherapy department (138 individuals) from 2009 to 2013 were included. Data analysis considered absolute and relative frequencies of the variables of interest. Results: Most patients were female (55\%) and the mean age was 35.0 years $( \pm 16.8)$. Most users were usingantiretroviral therapy and had 4 to 10 years (51.8\%) of the HIV diagnosis. Many patients have comorbidities and the most prevalent was cerebral toxoplasmosis. The most common physical complaints were hemiparesis, pain, alteration in muscle tone and lipodystrophy. Conclusion: According the symptomatic profile found, expanding the role of physiotherapists for infected individuals with HIV is necessary, since the physiotherapy has a wide range of preventive and therapeutic interventions that can increase functionality, independence level and social participation.
\end{abstract}

Keywords: Physiotherapy. HIV (AIDS Virus). Functionality.

\footnotetext{
* TBA: undergrad, e-mail: tamaiara@hotmail.com

EPS: BS, e-mail: elisps@hotmail.com

KOBS: PhD, e-mail: kionnabernardes@ufba.br
} 


\section{Resumo}

Introdução: Com a modificação do perfil dos indivíduos vivendo com HIV/AIDS, relacionada à cronicidade destas condições, torna-se necessário um melhor entendimento das alterações clínicas provocadas pela doença. objetivo: Caracterizar os sintomas físicos de indivíduos com HIV/AIDS do ambulatório de fisioterapia de um centro de referência para o tratamento de HIV/AIDS. Métodos: Realizou-se um estudo do tipo descritivo com abordagem quantitativa. Foram incluídos todos os usuários cadastrados no setor de fisioterapia, no período de 2009 a 2013, totalizando 138 indivíduos. A análise dos dados considerou frequências relativas e absolutas das variáveis de interesse. Resultados: Os pacientes foram caracterizados pela maioria do sexo feminino (55\%) e média de idade de 35,0 anos ( $\pm 16,8)$. A maioria utilizava a terapia antirretroviral, com tempo de diagnóstico entre 4 e 10 anos. Foi comum a presença comorbidades, sendo a mais prevalente a neurotoxoplasmose. As queixas físicas mais frequentes foram hemiparesia, dor, alteração do tônus e lipodistrofia. Conclusão: Diante do perfil sintomatológico apresentado, é necessária a ampliação da atuação dos fisioterapeutas com os indivíduos com HIV/AIDS, visto que, a fisioterapia possui uma série de medidas preventivas e terapêuticas capazes de aumentar a funcionalidade, o grau de independência e a participação social.

Palavras-chave: Fisioterapia. HIV (Vírus da AIDS). Funcionalidade.

\section{Introduction}

The acquired immunodeficiency syndrome (AIDS) is considered a pandemic. It is a public health problem in many countries (1). Current estimates show that there are 34 million people worldwide with the human immunodeficiency virus (HIV), which reflects an increase in the rate of infected individuals (2). In Brazil there were about 734.000 infected people with HIV/AIDS in 2014 (3). Since the first notification until mid-October 2015, there were recorded 26.268 AIDS cases in Bahia (4).

Advances in antiretroviral therapy (ART) and the increase of the current incidence of the disease and the life expectancy of patients make necessary new thinking about ways of approaches to HIV/AIDS, for implementation and maintenance of public politics for prevention and assistance more and more efficient and accessible to the whole population (5). AIDS results in atypical clinical manifestations in physical and emotional conditions of infected people, especially to comorbidities due to immunosuppression (6). Immunosuppression or adverse effects of antiretroviral drugs cause clinical and functional disorders especially degeneration of the central nervous system, opportunistic infections, dyslipidemia, lipodystrophy, type II diabetes mellitus, lactic acidosis, depression, muscle atrophy and disability (7).

In terms of maintaining physical and functional capacity, the physiotherapy becomes relevant for restoring mobility and function (8). However, the physiotherapist role in health promotion in infected individuals is still not recognized (9). Nowadays, there is a search for better opportunities and treatment conditions to ensure quality of life of these individuals.

Therefore, the identification of the profile of the manifestations of the physical and functional disorders becomes important to plan and implement programs that reach the real needs of these individuals and the formulation of strategies for the prevention of disabilities in specific groups. So, this study aimed to characterize the clinical profile and the treatments received by infected individuals accompanied by Physiotherapy Department in a Specialized Reference Center.

\section{Methods}

Study Design

This is a descriptive study with a quantitative approach, performed in the Physiotherapy Department of a Reference Center in HIV/AIDS, called Centro Estadual Especializado em Diagnóstico, Assistência e Pesquisa CEDAP, located in Salvador, Bahia.

\section{Study Population}

It was evaluated all registered users in the Physiotherapy Department from 2009 to 2013, totaling 138 individuals who were chosen by spontaneous demand or clinical indication. The research was preceded by the approval of the Comitê de Ética em Pesquisa da 
Escola Baiana de Saúde Pública, through registration in Brazil No. 19498713.0.0000.0052.

Instrument and data collection

Data collection was obtained by secondary sources, through a database made by variables of interest taken from the Physiotherapy Department. Assistance to users was provided according the standard service offered. It was extracted theses variables of interest:

1) General characteristics: gender (male, female); age group $(0$ - 15, 16 - 35, 35 - 46, > 46);

2) Work Situation (retired, unemployed/employed, be on sick leave, housemaid (yes, no);

3) Clinical characteristics and treatment of disease: ART used (yes, no), medical diagnosis time (0$3,4-10,>10$ ), comorbidity (yes, no); type of comorbidity (cerebral toxoplasmosis, tuberculosis, syphilis, Human T-Cell Lymphotropic Virus (HTLV), diabetes mellitus, hypertension, others); comorbidity coexistence (yes, no); pregnancy (yes, no); CD4 levels (<200, 201-350, > $350)$, viral load $(<50,>50)$; physical symptoms: main complaint, muscle tone (normal, hypotonic, hypertonic); paresis (lower limb, upper limb, hemibody); pain (yes, no); presence of deformities (yes, no); orthoses used (yes, no); respiratory disorders (yes, no); he/she attended a physiotherapy session before (yes, no); number of these physiotherapy sessions.

\section{Data analysis}

The database was organized in Microsoft Excel ${ }^{\circledR}$ software and the absolute and relative frequencies were calculated for description of the variables of interest. The continuous variables were evaluated through measures of centralization and dispersion tendency. The graphics data have shown in the SPSS15 ${ }^{\circledR}$ program.

\section{Results}

Users of the service have characterized by most women $(55.1 \%)$; the average age was 35.0 years $( \pm$ $16.8)$; the prevalent age group was $36-45$ years (34\%) followed for greater than 46 years $(25.7 \%)$. The work situation showed that (30.0\%) were unemployed and (34.0\%) employees. (93.2\%) did not practice physical activities (Table 1).
Table 1 - General Characteristics of infected users with HIV in a Physiotherapy Department in a Specialized Reference Center in Salvador-Bahia from 2009 to 2013

\begin{tabular}{lcc}
\hline \multicolumn{1}{c}{$\begin{array}{c}\text { General } \\
\text { Characteristics }\end{array}$} & $\begin{array}{c}\text { Number of } \\
\text { responses }\end{array}$ & $\%$ \\
\hline Gender & (136) & \\
Female & 75 & 55.1 \\
Male & 61 & 44.9 \\
Age Group & $(\mathbf{1 3 6 )}$ & \\
0 - 15 years & 20 & 14.7 \\
16 - 35 years & 34 & 25 \\
36 - 45 years & 47 & 34.6 \\
$>$ 46 years & 35 & 25.7 \\
Work Situation & $\mathbf{( 1 1 0 )}$ & \\
Retired & 17 & 15.5 \\
Unempolyed & 33 & 30.0 \\
Be on sick leave & 15 & 13.6 \\
Housemaid & 6 & 5.5 \\
Employed & 38 & 34.5 \\
Physical Activity & $\mathbf{( 1 0 4 )}$ & \\
Yes & 62.3 \\
No & 96 & \\
\hline
\end{tabular}

Towards the antiretroviral therapy used was observed that among 137 interviewees, (77.4\%) used drugs. Most users had 4 to 10 years (51.8\%) of the HIV diagnosis when they sought the physiotherapy services. Most users had comorbidities (80.3\%) and the highest prevalence was cerebral toxoplasmosis with (36.2\%). The comorbidity coexistence was identified in $(35.1 \%)$ of infected individuals. About the immune status, $(60.0 \%)$ had CD4 level $>350$ in relation to the virological parameters; (57.8\%) had viral load $<50$ and (4.8\%) were pregnant (Table 2). 
Table 2 - Clinical Characteristics and effects of the disease of infected users with HIV in a Physiotherapy Department in a Specialized Reference Center in Salvador-Bahia from 2009 to 2013

\begin{tabular}{|c|c|c|}
\hline Clinical Characteristics & $\begin{array}{l}\text { Number of } \\
\text { responses }\end{array}$ & $\%$ \\
\hline ART used & (137) & \\
\hline Yes & 106 & 77.4 \\
\hline No & 31 & 22.6 \\
\hline Medical Diagnosis Time & (114) & \\
\hline $0-3$ & 39 & 34.2 \\
\hline 4 a 10 & 59 & 51.8 \\
\hline$>10$ & 16 & 14 \\
\hline Comorbidity & (117) & \\
\hline Yes & 94 & 80.3 \\
\hline No & 23 & 19.7 \\
\hline Disease & (94) & \\
\hline Cerebral toxoplasmosis & 34 & 36.2 \\
\hline Tuberculosis & 15 & 16 \\
\hline Syphilis & 3 & 3.2 \\
\hline $\begin{array}{c}\text { Human T-Cell } \\
\text { Lymphotropic Virus } \\
\text { (HTLV) }\end{array}$ & 7 & 7.4 \\
\hline Diabetes Mellitus & 5 & 5.3 \\
\hline Hypertension & 5 & 5.3 \\
\hline Others & 25 & 26.6 \\
\hline $\begin{array}{l}\text { More than one } \\
\text { comorbidity }\end{array}$ & (117) & \\
\hline Yes & 41 & 35.1 \\
\hline No & 76 & 64.9 \\
\hline Pregnancy & (69) & \\
\hline Yes & 6 & 8.7 \\
\hline No & 63 & 91.3 \\
\hline CD4 Level & (90) & \\
\hline$<200$ & 21 & 23.3 \\
\hline 201 a 350 & 15 & 16.7 \\
\hline$>350$ & 54 & 60.0 \\
\hline Viral Load & (90) & \\
\hline$<50$ & 52 & 57.8 \\
\hline$>50$ & 38 & 42.2 \\
\hline
\end{tabular}

Physical symptoms were investigated and it was found a prevalence of hemiparesis in (34.1\%). The tone muscle changes were identified in (26.7\%) of the users: $(18.1 \%)$ in hypertonic and (8.6\%) in hypotonic. The presence of deformities was only described in (8.1\%) of the physiotherapy users furthermore only (18.4\%) of the respondents reported that have attended a physiotherapy session before and (19.0\%) were using an auxiliary device to march in the first evaluation. Regarding the respiratory disorders, (87.4\%) did not have this problem (Table 3).

Table 3 - Characterization of physical symptomatology among infected users with HIV in a Physiotherapy Department in a Specialized Reference Center in Salvador-Bahia from 2009 to 2013

\begin{tabular}{|c|c|c|}
\hline Physical Repercussions & $\begin{array}{l}\text { Number of } \\
\text { responses }\end{array}$ & $\%$ \\
\hline Main Complaint & (85) & \\
\hline Hemiparesis & 29 & 34.1 \\
\hline Paresis & 14 & 16.5 \\
\hline $\begin{array}{l}\text { Delayed Psychomotor } \\
\text { development }\end{array}$ & 19 & 22.4 \\
\hline Lipodystrophy & 4 & 4.7 \\
\hline Fatigue & 2 & 2.4 \\
\hline Paresthesia & 4 & 4.7 \\
\hline Others & 13 & 15.3 \\
\hline Muscle Tonus & (105) & \\
\hline Normal & 77 & 73.3 \\
\hline Hypotonic & 9 & 8.6 \\
\hline Hypertonic & 19 & 18.1 \\
\hline Paresis & (64) & \\
\hline Lower limbs & 27 & 42.2 \\
\hline Upper limbs & 6 & 9.4 \\
\hline Hemibody & 31 & 48.4 \\
\hline Pain & (109) & \\
\hline Yes & 66 & 60.6 \\
\hline No & 43 & 39.4 \\
\hline Deformities & (99) & \\
\hline Yes & 8 & 8.1 \\
\hline No & 91 & 91.9 \\
\hline Respiratory disorders & (103) & \\
\hline Yes & 13 & 12.6 \\
\hline No & 90 & 87.4 \\
\hline $\begin{array}{l}\mathrm{He} / \text { she attended a } \\
\text { physiotherapy session before }\end{array}$ & (98) & \\
\hline Yes & 18 & 18.4 \\
\hline No & 80 & 81.6 \\
\hline Orthoses used & (100) & \\
\hline Yes & 19 & 19.0 \\
\hline No & 81 & 81.0 \\
\hline
\end{tabular}


Associating the treatment frequency and comorbidities, it was observed that the amount of sessions was higher in patients with cerebral toxoplasmosis sequelae: about (42.00\%) and a portion of these infected individuals attended more than 10 physiotherapy sessions and
(37.00\%) less than 10 ones. Regarding the minimum accession around $(5.00 \%)$ of infected patients with syphilis attended less than 10 physiotherapy sessions. This value was quite close to a part of the infected individuals with diabetes (Figure 1).

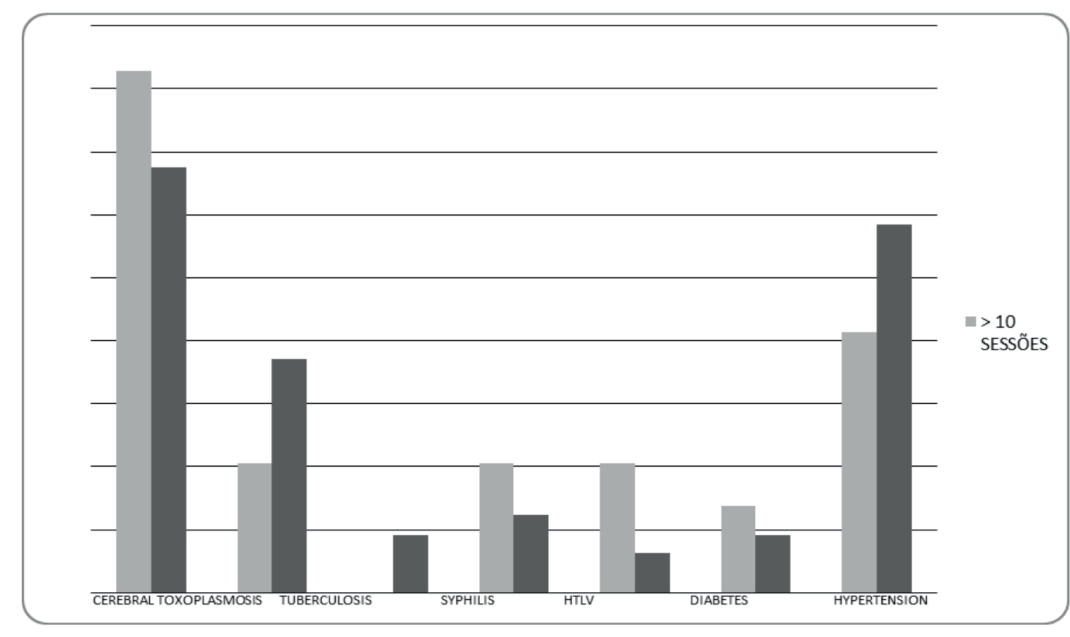

Figure 1 - Distribution of comorbidities according number of physiotherapy sessions for infected users with HIV in a Physiotherapy Department in a Specialized Reference Center in Salvador-Bahia from 2009 to 2013.

\section{Discussion}

The study allowed us to describe the symptomatic profile of individuals with HIV in the Physiotherapy Department in a Specializes Reference Center in northeastern Brazil. Most of the users were female and aged 36-45 years. Men asked for health service only when they had strong symptoms, in other words, they value more the healing practices and do not recognize the needs of preventive guidelines. Prevention, promotion and immediate treatment were regarded as mandatory for women (10).

Over time, the stage of the HIV epidemic was modified and changed the epidemiological profile due to awareness of the care provided to many infected groups and the availability of antiretroviral treatment and recognition that everyone is vulnerable and not only specifics groups $(11,12,13)$. In this study, it used to utilize the ART.

Lately it has also seen changes in the clinical symptoms and physical repercussions of infected individuals. Disease symptoms are associated with opportunistic infections, secondary malignancies, neurologic and cardiovascular manifestations and these changes are known as immunopathogenesis of AIDS (14). The use of ART brought benefits to these individuals as the improvement of the clinical outcomes, control of the disease progression and reduction of mortality rate (15). So the antiretroviral therapy made the HIV infection a chronic disease with low mortality but with metabolic and functional differences that have an effect on infected individuals (16).

Recent studies have shown that ART is an effective treatment to control the disease and produce survival increases and virus transmission decreases due to the improvement of the immune system by suppression of viral replication $(17,18)$. Despite advances in the HIV treatment, the chronicity of the disease and the prolonged use of drug produce side effects such as (19) dyslipidemia, insulin resistance, cardiovascular risk increases, intra-abdominal fat increases, peripheral fat loss, neurological diseases (20). In addition to fatigue, nausea, vomiting, diarrhea and lipodystrophy, these symptoms aid to the discontinuation of the medication and result in an increase viral load in the blood and a decrease in the Tlymphocytes CD4 $(21,22)$.

The studied group uses the ART and showed the presence of comorbidities and symptoms related to neurologic and cardiovascular diseases too. Although the therapeutic effects of treatment are beneficial to 
survival rates, the side effects and the progression of the infection are still highly variable among individuals and depend on the variety of environmental and genetic factors (19).

The most common neurologic manifestation among infected individuals with HIV includes cerebral toxoplasmosis. This condition causes physical, cognitive and psychiatric damages and reduces the quality of life and strength for daily activities. Thus, early diagnosis and therapeutic intervention should be implemented minimize complications (23).

The highest frequency in physiotherapy sessions was among users who had cerebral toxoplasmosis due to evident uncomfortable and functional sequelae. An expanded approach to prevent, control the risk factors related to neurologic and cardiovascular disease and consider viable strategies within a health public context is essential. Some interventions have been shown such as changes in lifestyle, nutrition and physical monitoring for infected individual with $\operatorname{HIV}(24,25)$.

The diversity of changes in the clinical context of infected individuals with HIV furthers several physical symptoms. In this study, the presence of hemiparesis, pain and lipodystrophy was observed. Such conditions alter functionality, physical condition and quality of life, and especially reduce the mobility. So they cause sequelae in different systems in the body and bring on functional dependence. However, the multidisciplinary team aims to promote the improvement of multidimensional quality of life (physical, psychological, social and spiritual) and thus relieve the symptoms caused by this disease (26).

In this context, the physiotherapist role stands out due to the possibility of this clinical care promotes prevention and treatment of these symptoms. The multidisciplinary team must assist infected individuals with HIV. The physiotherapist may introduce physical training as a complementary strategy for these individuals, in addition or not the use of the ART. These additional exercises aim to provide benefits in the cardiorespiratory, muscular, anthropometric and psychological conditions without inducing immunosuppression $(27,28)$.

Infected individuals with HIV have incapacitating motor deficit and this information shows that it is important the physiotherapeutic care as a component to join the multidisciplinary team (29).

The therapeutic approach in this department gives priority to enhancement of functionality. Treatments mediated by main complaint are especially composed of conventional kinesiotherapy techniques, physical conditioning exercises, breathing exercises, manual therapy and strengthening exercises. These processing help the motor and respiratory restoration and pain relief.

Good conduct physiotherapeutic is related to an appropriate medical evaluation to be established the treatment priorities. These procedures are passive and active-assisted manipulation. They promote the stretching of the upper and lower limbs and kinesiotherapy to gain and maintain balance and coordination. The physiotherapeutic procedures are showing good results in the interventions of the sequelae of cerebral toxoplasmosis (hemiparesis and ataxia) and the neurologic impairment that affect infected individuals with HIV (30).

The International Classification of Functioning, Disability and Health (ICF) can be used to describe how HIV impacts the health and function of infected people in different environmental contexts. The ICF provides a useful framework to achieve describe the functionality of infected individuals with HIV and the impact of the environment (18).

Most of the individuals in this study get belatedly the physiotherapeutic services when considering the period of the disease diagnosis and it was common comorbidities. It is essential to emphasize the importance of preventive physiotherapy before the changes are already present because it improves the functional capacity and reduces the physical and emotional impacts of comorbidities and clinical symptomatology.

Not using the drug treatment with ART is considered one of the biggest problems in the syndrome control (31) and contributes to the increase in mortality and morbidity rates. It is also related to treatment failure and facilitates the emergence of resistant HIV strains to used drugs. In these cases are necessary to use combination drugs and they may further compromise the adherence to treatment (32).

The monitoring of accession must be used as a strategy to support the patient and helps the health team to identify difficulties. These procedures allow designing an intervention plan according the demands and needs of each user (33).

It can be seen the need for integrated actions with politics public to obtain greater responsibility and commitment with preventive and control actions of HIV infections $(34,35)$.

The physiotherapeutic treatment for infected individuals with HIV promotes quality of physical, psychological and social life by providing educational and therapeutic activities applied to prevention of functional 
disorders in infected individuals with HIV. In the clinical and functional scope, the physiotherapist is able to prescribe therapeutic procedures according to the objective and subjective need of each infected individuals with HIV when inserted in a (public or private) multidisciplinary health team (34).

\section{Conclusion}

According the presented dysfunctions is evident that infected individuals with HIV need the therapeutic services. It stands out the need for preventive approach to delay or prevent the common sequelae to the chronicity of this disease and generates functional independence and quality of life. The physiotherapist can promote conversations in collective groups and thus expands the field action and clinical intervention.

The study has a census approach but it is relevant the loss of information on some variable of interest. This fact shows weakness in the records, however it do not preclude the interpretation of the main results presented. The study describes the profile of infected users with HIV in a Physiotherapy Department and discusses the intervention therapeutic possibilities. Others clinical approach studies are necessary to evaluation the efficacy of treatment and to formulate evidences.

\section{References}

1. Sousa GML, Maia EANS, Pelissari DM, Lima JFEF, Sena JM, Cechinel MP. Co-infecção Leishmania - HIV no Brasil: aspectos epidemiológicos, clínicos e laboratoriais. Epidemiol Serv Saude. 2011;20(4):519-26.

2. Unaids. Global Report: Unaids Report on the Global AIDS Epidemic 2012; Geneva: UNAIDS; 2012. 8 p.

3. Ministério da Saúde, Secretaria de Vigilância em Saúde Departamento de DST, Aids e Hepatites Virais. Boletim Epidemiológico - Aids e DST. Brasília; 2014. Portuguese.

4. Secretária da Saúde do Estado da Bahia - SUVISA/DIPEV. Boletim Informativo no 04 HIV/AIDS 2015. Portuguese.

5. Santos NJ, Barbosa RM, Pinho AA. Contextos de vulnerabilidade para o HIV entre mulheres brasileiras. Cad Saude Publica. 2009;25(2):321-33.

6. Lambert N, Mehta B, Walters R, Eron JJ. Chagasic encephalitis as the initial manifestation of AIDS. Ann Intern Med. 2006;144(12):941-3.
7. Huang L, Quartin A, Jones D, Havlir DV. Intensive care of patients with HIV infection. N Engl J Med. 2006;355(2):173-81.

8. Myezwa H, Stewart A, Solomon P, Becker P. Topics on HIV/AIDS for Inclusion into a Physical Therapy Curriculum: Consensus through a Modified Delphi Technique. J Phys Ther Educ. 2012;26(2).

9. Kinirons SA, Sandy D. The acute care physical therapy HIV/AIDS patient populacion: a descriptive study. J Int Assoc Provid AIDS Care. 2015;14(1):53-63.

10. Schraiber LB, Figueiredo WS, Gomes R, Couto MT, Pinheiro TF, Machin R, et al. Necessidades de saúde e masculinidades: atenção primária no cuidado aos homens. Cad Saude Publica. 2010;26(5):961-70.

11. Gomes AMT, Barbosa BFS, Oliveira DC, Wolter RMCP, Silva MVG. As representações sociais de enfermeiros sobre a criança soropositiva para HIV: interface com o cuidar. Rev Enferm UERJ. 2011;19(1):14-9.

12. Lima DJM, Araújo ACM, Mendes IC, Oriá MOB, Aquino OS, Pinheiro AKB. Completude e consistência dos dados de gestantes HIV positivas notificadas. Rev Enferm UERJ. 2014;22(3):321-32.

13. Parkhurst JO. Structural approaches for prevention of sexually transmitted HIV in general populations: definitions and an operational approach. J Int AIDS Soc. 2014;17:19052.

14. Bernstein WB, Little RF, Wilson WH, Yarchoan R. Acquired immunodeficiency syndrome-related malignancies in the era of highly active antiretroviral therapy. Int J Hematol. 2006;84(1):3-11.

15. Chiou PY, Kuo BI, Lee MB, Chen YM, Chuang P, Lin LC. A programme of symptom management for improving quality of life and drug adherence in AIDS/HIV patients. J Adv Nurs. 2006;55(2):169-79.

16. Aberg JA. Cardiovasculares complications in HIV management: past, presente and future. J Acquir Immune Defic Syndr. 2009;50(1):54-64.

17. HIV-CAUSAL Collaboration, Ray M, Logan R, Sterne JA, Hernández-Díaz S, Robins JM, et al. The effect of combined antiretroviral therapy on the overall mortality of HIV-infected individuals. AIDS. 2010;24(1):123-37.

18. Ruaro JA, Ruaro MB, Souza DE, Fréz AR, Guerra RO. Panorama e perfil da utilização da CIF no Brasil - uma década de história. Rev Bras Fisioter. 2012;16(6):454-62. 
19. Chatterjee K. Host genetic factores in susceptibility to HIV-1 infection and progression to AIDS. J Genet. 2010;89(1):109-16.

20. Juchem GM, Lazzarotto AR. Treinamento físico na síndrome lipodistrófica: revisão sistemática. Rev Bras Med Esporte. 2010;16(4):310-3.

21. Remor E, Milner-Moskovics J, Preussler G. Adaptação brasileira do "Cuestionario para la Evaluación de la Adhesión al Tratamiento Antiretroviral". Rev Saude Publica. 2007;41(5):685-94.

22. Ruiz-Pérez I, Olry de Labry-Lima A, Prada-Pardal JL, Rodríguez-Baño J, Causse-Prados M, López-Ruz MA, et al. Impact of demographic and psychosocial factors on adherence to antiretroviral treatment. Enferm Infecc Microbiol Clin. 2006;24(6):373-8.

23. Christo PP. Alterações cognitivas na infecção pelo hiv e aids. Rev Assoc Med Bras. 2010;56(2):242-7.

24. Masiá-Canuto M, Morell EB, Rodero FG. Alteraciones lipídicas y riesgo cardiovascular asociado a la terapia antirretroviral. Enferm Infecc Microbiol Clin. 2006;24(10):637-48.

25. Valente AMM, Reis AF, Machado DM, Succi RCM, Chacra AR. Alterações metabólicas da síndrome lipodistrófica do HIV. Arq Bras Endocrinol Metab. 2005;49(6):871-81.

26. Ministério da Saúde, Secretaria de Vigilância em Saúde Programa Nacional de DST e Aids. Rotinas de Assistência Domiciliar Terapêutica (ADT) em HIV/Aids, Série Manuais no 70. Brasília; 2007. Portuguese.

27. Ciccolo JT, Jowers EM, Bartholomew JB. The benefits of exercise training for quality of life in HIV/AIDS in the Post-HAART era. Sports Med. 2004;34(8):487-99.

28. Terry L, Sprinz E, Stein R, Medeiros NB, Oliveira J, Ribeiro JP. Exercise training in HIV-1-infected individuals with dyslipidemia and lipodystrophy. Med Sci Sports Exerc. 2006;38(3):411-7.

29. Parenti CF, Pereira LMR, Brandão ZS, Silvério APC. Perfil dos pacientes com aids acompanhados pelo Serviço de Assistência Domiciliar Terapêutica do Município de Contagem, Estado de Minas Gerais, Brasil, 2000-2003. Epidemiol Serv Saude. 2005;14(2):91-6.
30. Nogueira JA. Fisioterapia no contexto da assistência domiciliar terapêutica: estudo de pacientes com AIDS [master's thesis]. Rio de Janeiro: Escola Nacional de Saúde Pública da Fundação Oswaldo Cruz; 2000. Portuguese.

31. Silva MCF, Ximenes RAA, Miranda DBF, Arraes LWMS, Mendes M, Melo ACS, et al. Risk-factors for non-adherence to antiretroviral therapy. Rev Inst Med Trop Sao Paulo. 2009;51(3):135-9.

32. Neves LASN, Reis RK, Gir E. Adesão ao tratamento por indivíduos com a co-infecção HIV/tuberculose: revisão integrativa da literatura. Rev Esc Enferm USP. 2010;44(4):1135-41.

33. Polejack L, Seidl EMF. Monitoramento e avaliação da adesão ao tratamento antirretroviral para HIV/ aids: desafios e possibilidades. Cien Saude Colet. 2010;15(1):1201-8.

34. Galvão MTG, Gouveia AS, Carvalho CML, Costa E, Freitas JG, Lima ICV. Temáticas produzidas por portadores de HIV/aids em grupo de autoajuda. Rev Enferm UERJ. 2011;19(2):299-304

35. Marta CB, Leite JL, Peregrino AAF, Schutz V, Francisco MTR, Magnago C. Custos da adesão ao tratamento da Síndrome da Imunodeficiência Adquirida: estudo transversal. Rev Enferm UERJ. 2014;22(2):193-9.

36. Nobre AQTC, Costa IS, Bernardes KO. A fisioterapia no contexto do HIV/AIDS. Fisioter Mov. 2008;21(4):11-8.

Received in 07/18/2015

Recebido em 18/07/2015

Approved in 05/12/2016 Aprovado em 12/05/2016 